\title{
AKTIVITAS ANTIOKSIDAN DAN IDENTIFIKASI SENYAWA EKSTRAK JAMUR LINGZHI (Ganoderma lucidum) DENGAN LIQUID CHROMATOGRAPHY-MASS SPECTROMETRY (LC-MS)
}

\author{
Farida Nuraeni $^{1 *}$, Septi Bernadetha Br Sembiring ${ }^{1}$ \\ ${ }^{1}$ Program Studi Kimia FMIPA Universitas Pakuan, Bogor \\ e-mail: nuraeni.farida@yahoo.com
}

diterima: 23 Juli 2019; direvisi: 20 Agustus 2019; disetujui: 05 September 2019

\begin{abstract}
ABSTRAK
Jamur lingzhi banyak digunakan sebagai pengobatan alternatif untuk menurunkan tekanan darah dan kadar gula dalam darah, untuk memaksimalkan potensi dari jamur lingzhi dilakukan uji antioksidan. Penelitian ini bertujuan menentukan potensi aktivitas antioksidan ekstrak air dan ekstrak etanol 70\% dari jamur lingzhi dengan variasi lama waktu ekstraksi secara maserasi serta identifikasi senyawa dengan Liquid Chromatography Mass Spectrometry (LC-MS). Penelitian ini diawali dengan determinasi dari jamur lingzhi yang masih segar kemudian dibuat simplisia dan diekstrak secara maserasi dengan variasi waktu lama perendaman 24 jam, 48 jam dan 72 jam masing-masing dengan 2 pelarut yaitu air dan etanol 70\%. Ekstrak diuji fitokimia dilanjutkan dengan pengujian aktivitas antioksidan ekstrak jamur lingzhi dengan metode DPPH. Kemudian dilakukan identifikasi senyawa dengan Liquid Chromatography-Mass Spectrometry (LC-MS). Berdasarkan hasil Penelitian bahwa maserasi selama 1 jam (1 hari) jamur lingzhi dengan ekstraksi etanol $70 \%$ berpotensi sebagai antioksidan dengan nilai IC50 94,83 ppm. Hasil identifikasi dengan LC-MS pada ekstrak etanol $70 \%$ sebagai senyawa yang berpotensi sebagai antioksidan adalah senyawa Bisphenol $M$, dan 1-\{[2-(3,4- Dimethoxyphenyl) ethyl]amino\}-3-methyl-2-octylpyrido[1,2-a]benzimidazole-4-carbonitrile.
\end{abstract}

\section{Kata Kunci: Jamur lingzhi, radikal bebas, antioksidan, LCMS}

\section{ANTIOXIDANT ACTIVITY AND IDENTIFICATION of LINGZHI MUSHROOM EXTRACT (Ganoderma lucidum) WITH LIQUID CHROMATOGRAPHY-MASS SPECTROMETRY (LC-MS)}

\begin{abstract}
Lingzhi mushroom is widely used as an alternative treatment to reduce blood pressure and blood sugar levels, to maximize the potential of the Lingzhi fungus antioxidant tests are carried out. This study aims to determine the potential antioxidant activity of water extract and $70 \%$ ethanol extract of Lingzhi mushroom with maceration extraction time variation and identification of compounds with Liquid Chromatography Mass Spectrometry (LC-MS). This research begins with the determination of fresh lingzhi mushrooms then made simplicia and extracted by maceration with time variation with soaking time of 24 hours, 48 hours and 72 hours each with 2 solvents namely water and $70 \%$ ethanol. The extract was tested by phytochemistry followed by testing the antioxidant activity of Lingzhi mushroom extract (ganoderma lucidum) by DPPH method. Then the compounds were identified by Liquid Chromatography-Mass Spectrometry (LC-MS). Based on the results of research that maceration for 1 hour (1 day) Lingzhi mushroom with $70 \%$ ethanol extraction has the potential as an antioxidant with an IC50 value of $94.83 \mathrm{ppm}$. The results of identification with LC-MS in 70\% ethanol extract as a compound that has potential as an antioxidant are Bisphenol M compounds, and 1- - [[2- (3,4-Dimethoxyphenyl) amino]\} -3-methyl-2-octylpyrido [1 , 2-a] benzimidazole4-carbonitrile.
\end{abstract}

Keywords: Lingzhi mushrooms, free radicals, antioxidants, LCMS 


\section{PENDAHULUAN}

Antioksidan merupakan senyawa yang dapat menghambat oksigen reaktif dan radikal bebas dalam tubuh. Senywa antioksidan ini akan menyerahkan satu atau lebih elektron kepada radikal bebas sehingga menjadi bentuk molekul yang normal kembali dan menghentikan berbagai kerusakan yang ditimbulkan (Sasikumar, 2009). Antioksidan mampu melindungi tubuh terhadap kerusakan yang disebabkan senyawa oksigen reaktif, mampu menghambat terjadinya penyakit degeneratif seperti diabetes, kanker, inflasi jaringan dan penuaan dini (Middleton, 2000).

Jamur lingzhi (Ganoderma lucidum) merupakan salah satu simplisia yang banyak digunakan oleh masyarakat sebagai pengobatan alternatif untuk menurunkan tekanan darah dan kadar gula dalam darah. Khasiat tanaman tersebut disebabkan oleh adanya senyawa kimia yang dikandungnya. Menurut Jaelani (2008) bahwa zat utama yang terkandung dalam jamur lingzhi adalah ganodermin, ganoderan, asam ganodermin, triterpenoid, adenosin, peptidaglukan, germanium dan polisakarida (betaglukan).

Kandungan lain dari jamur lingzhi yaitu thiamin, riboflavin, niasin, dan biotin juga beberapa mineral antara lain seperti kalium, fosfor, kalsium, natrium, tembaga dan magnesium. Sebagai salah satu untuk mengoptimalkan pemanfaatan dari jamur lingzhi bagi kesehatan bagi manusia maka dilakukan penelitian menguji aktivitas antioksidan ekstrak etanol $70 \%$. dan ekstrak air dengan perbandingan waktu perendaman maserasi selain itu dilakukan juga uji fitokimia dalam jamur lingzhi. Uji aktivitas antioksidan ekstrak jamur lingzhi dengan menggunakan metode DPPH (1,1-difenil-2pikrilhidrazil) dengan pelarut air dan etanol 70\%. Identifikasi senyawa hasil dari aktivitas antioksidan dengan menggunakan instrumen Liquid Chromatography Mass Spectrometry (LC-MS).

\section{BAHAN DAN METODE}

Penelitian ini diawali dengan determinasi dari jamur lingzhi yang masih segar. Kemudian jamur lingzhi diayak dengan ayakan mesh no 40 menghasilkan simplisia jamur lingzhi. Setelah itu dilakukan analisis kadar air dan ekstraksi maserasi. Ekstraksi maserasi tersebut dengan variasi waktu dengan lama perendaman 24 jam, 48 jam dan 72 jam masing-masing dengan 2 pelarut yaitu air dan etanol 70\%. Ekstrak tersebut dilakukan pengujian melalui analisa kimia yaitu uji fitokimia antara lain alkaloid, flavonoid, saponin, tanin dan terpenoid. Dilanjutkan dengan analisis aktivitas antioksidan dengan ekstrak etanol $70 \%$ dan ekstrak air jamur lingzhi dengan Spektrofotometer UV/VIS. Kemudian diidentifikasi senyawa dengan Liquid Chromatography Mass Spectrometry (LC-MS)

\section{Determinasi Tanaman}

Sampel yang digunakan adalah jamur lingzhi yang diperoleh dari daerah Solo, Jawa Tengah. Jamur lingzhi tersebut dilakukan uji determinasi di pusat penelitian biologi Lembaga Ilmu Pengetahuan Indonesia (LIPI) Cibinong-Bogor.

\section{Pembuatan Simplisia}

Ditimbang jamur lingzhi sebanyak 2000 gram, dicuci dengan air yang mengalir sampai bersih, kemudian ditiriskan selanjutnya pengecilan ukuran dengan 40 mesh dan pengeringan selama 4 jam. Setelah kering, simplisia diserbukkan dengan lumpang, kemudian disimpan dalam wadah bersih dan tertutup rapat, yang selanjutnya akan digunakan dalam pengujian berikutnya.

\section{Analisa Kadar Air Simplisia Jamur Lingzi (DepKes RI, 2000)}

Cawan aluminium kosong dikeringkan dalam oven selama 15 menit dan didinginkan dalam desikator selama 10 menit, kemudian ditimbang (W0). Sebanyak 2 gram (W1) dimasukkan kedalam cawan. Cawan berisi sampel dikeringkan dalam oven suhu $105^{\circ} \mathrm{C}$ selama 3 jam. Cawan dipindahkan ke dalam desikator dan didinginkan selama 15 menit, lalu ditimbang 
kembali (W2). Penimbangan diulang hingga diperoleh bobot tetap. Kadar air contoh dihitung dengan persamaan berikut:

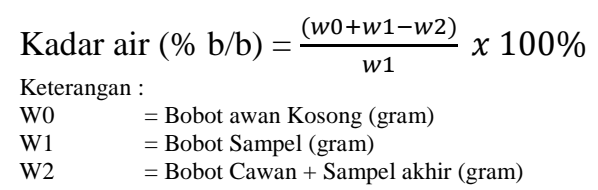

\section{Ekstraksi Jamur Lingzhi}

\section{(dengan Pelarut Air dan Etanol 70\%)}

Serbuk simplisia jamur lingzhi masingmasing sebanyak 20 gram diekstrak dengan menggunakan 1 liter etanol $70 \%$ dan 1 liter air di dalam maserator 1 hari (24 jam), 2 hari (48 jam) dan 3 hari (72 jam) dengan sesekali dikocok, kemudian dipekatkan ekstraknya dengan Rotary evaporator dan diuapkan dengan oven lalu ditimbang bobotnya. Kemudian dihitung rendemen dengan persamaan berikut :

Rendemen $=\frac{\text { Bobot ekstrak }}{\text { bobot sampel }} \times 100 \%$

\section{Pengujian Fitokimia}

Meliputi uji alkaloid,uji flavonoid,uji Saponin, uji Tanin dan uji Triterpenoid dansSteroid (DepKes RI, 1985)

Analisis Antioksidan dengan 1,1- difenil2-pikrilhidrazil (DPPH) (Chow, 2003)

a. Pembuatan Larutan DPPH 1 mM

Lebih kurang 19,716 mg DPPH (BM 394,32) ditimbang, lalu dilarutkan dengan metanol pro analis hingga $100 \mathrm{ml}$, kemudian ditempatkan dalam botol gelap.

\section{b. Penentuan Panjang Gelombang Maksimum \\ Penentuan panjang gelombang} maksimum dimulai dengan dipipet $1 \mathrm{ml}$ larutan DPPH 1mM kemudian dimasukkan kedalam labu ukur $5 \mathrm{ml}$ yang seluruh bagian labu ukurnya telah ditutup dengan alumunium foil dan ditambahkan metanol p.a sampai tanda batas, lalu dihomogenkan dan diinkubasi terlabih dahulu selama waktu optimum pada suhu $37^{\circ} \mathrm{C}$, setelah itu serapanya diukur pada panjang gelombang
$400 \mathrm{~nm}$ sampai dengan $600 \mathrm{~nm}$ dengan menggunakan Spektrofotometri UV-VIS.

\section{c. Penentuan Waktu Inkubasi Optimum}

Larutan DPPH 1mM dipipet sejumlah 1 $\mathrm{ml}$ ke dalam labu ukur $5 \mathrm{ml}$ yang seluruh bagiannya telah ditutup dengan alumunium foil, ditambahkan metanol p.a sampai tanda batas, lalu dihomogenkan. Serapan diukur pada panjang gelombang maksimum tiap 10, 20, 30, 40, 50 dan 60 menit, serta ditentukan waktu optimum (waktu inkubasi yang memberikan serapan cukup stabil).

\section{d. Pembuatan Larutan Blanko}

Larutan DPPH $(0,2 \mathrm{mM})$ dipipet $1 \mathrm{ml}$ ke dalam tabung reaksi yang telah ditara 5 $\mathrm{ml}$, lalu ditambahkan metanol pro analis dan dihomogenkan selanjutnya inkubasi pada suhu $37^{\circ} \mathrm{C}$ selama waktu optimum. Serapan diukur menggunakan spektrofotometri UVVIS pada panjang gelombang maksimum.

\section{e. Pembuatan Deret Standar Vitamin C (kontrol positif)}

Sebanyak $50 \mathrm{mg}$ vitamin $\mathrm{C}$ ditimbang lalu dilarutkan dalam metanol di dalam labu ukur sampai $50 \mathrm{ml}$ sehingga diperoleh larutan standar vitamin $\mathrm{C}$ dengan konsentrasi 1000 ppm (larutan induk). Kemudian larutan vitamin $\mathrm{C}$ dibuat dalam beberapa konsentrasi yaitu 5 , 10, 15, 20 dan 25 ppm dengan cara memipet sebanyak 25 , $50,75,100$ dan $125 \mu 1$ larutan induk vitamin $\mathrm{C}$ kemudian ditambahkan $1 \mathrm{ml}$ larutan DPPH $1 \mathrm{mM}$ dan metanol p.a kedalam labu takar $5 \mathrm{ml}$ sampai tanda batas.

\section{f. Pembuatan Larutan Uji}

Ekstrak etanol $70 \%$ dan ekstrak air ditimbang sebanyak $50 \mathrm{mg}$ dimasukkan kedalam labu ukur $50 \mathrm{ml}$ kemudian dilarutkan dengan metanol sampai tanda batas, ini merupakan larutan induk (1000 ppm). Larutan uji dibuat dalam beberapa konsentrasi yaitu 100, 200, 300, 400 dan 500 ppm, dengan cara memipet sebanyak 500, 1000, 1500, 2000 dan $2500 \mu$ l larutan uji (1000 ppm) kemudian ditambahkan $1 \mathrm{ml}$ larutan DPPH $1 \mathrm{mM}$ dan metanol pro analis 
kedalam labu takar $5 \mathrm{ml}$ sampai tanda batas, dihomogenkan dan labu ditutup dengan alumunium foil.

\section{g. Uji Antioksidan dengan 1,1-difenil-2- pikrilhidrazil (DPPH)}

Larutan uji, larutan blanko dan larutan vitamin $\mathrm{C}$ (kontrol positif) kemudian segera diinkubasi pada suhu $37^{\circ} \mathrm{C}$ selama waktu optimum. Setelah itu, diukur serapannya dengan Spektrofotometri pada panjang gelombang maksimum yang sudah ditentukan. Penentuan dilakukan secara duplo. Pengukuran presentase hambatan terhadap DPPH dihitung dengan menggunakan rumus:

$$
\text { Hambatan }(\%)=\frac{\text { serapan blanko }- \text { serapan sampel }}{\text { serapan blanko }} \times 100
$$

\section{h. Nilai \% $\quad$ IC $_{50}$ (Inhibition \\ Concentration 50)}

Menentukan nilai $\mathrm{IC}_{50}$ diperoleh garis anatara $50 \%$ daya hambat dengan sumbu konsentrasi, dengan persamaan $\mathrm{y}=\mathrm{ax}+\mathrm{b}$, dimana $\mathrm{y}=50$ dan $\mathrm{x}$ adalah konsentrasi larutan uji yang mampu menghambat $50 \%$ larutan radikal bebas 1,1-difenil-2pikrilhidrazil $\left(\mathrm{IC}_{50}\right)$.

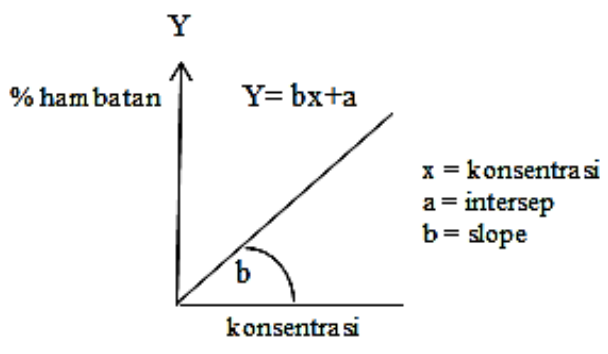

Gambar 1. Penentuan Nilai $\% \mathrm{IC}_{50}$

\section{Identifikasi Senyawa Aktif Ekstrak dengan LC-MS}

Identifikasi senyawa menggunakan Liquid Chromatography-Mass Spectrometry (LC-MS) dilakukan pada ekstraksi jamur lingzhi dari pelarut etanol $70 \%$ yang memiliki nilai aktivitas antioksidan tertinggi. Sebanyak 0,5 gram ekstrak etanol $70 \%$. dilarutkan dalam $50 \mathrm{~mL}$ metanol pro analis. Larutan disaring menggunakan filter syringe 0,22 mikron, dimasukkan ke dalam vial $2 \mathrm{~mL}$, dan diinjeksikan ke sistem LCMS.

\section{HASIL DAN PEMBAHASAN}

Berdasarkan hasil determinasi di Herbarium Bogoriens bidang Botani Pusat Penelitian Biologi LIPI Cibinong, Bogor menyatakan bahwa sampel atau bahan yang digunakan dalam penelitian adalah Jamur Lingzhi (Ganoderma lucidum (Curtis) P. Karst) dengan suku Ganodermataceae.

Hasil pengukuran kadar air menunjukkan bahwa simplisia jamur lingzhi memiliki kadar air yaitu 7,9021 \%. Menurut (Menkes, 1994) parameter standar kadar air adalah tidak lebih dari $10 \%$. Uji fitokimia yang terdapat di dalam ekstrak air dan etanol $70 \%$, digunakan untuk mendeteksi awal senyawa fitokimia yang terkandung dalam jamur lingzhi. Hasil uji fitokimia ekstrak air dan etanol $70 \%$ dapat dilihat pada Tabel 3.

Tabel 3. Hasil Uji Fitokimia Ekstrak Air dan Etanol $70 \%$

\begin{tabular}{lcc}
\hline \multirow{2}{*}{ Uji } & \multicolumn{2}{c}{ Ekstrak } \\
\cline { 2 - 3 } & Air & Etanol 70\% \\
\hline Flavonoid & \multicolumn{1}{c}{-} \\
Alkaloid & & \\
& & \\
1. Wagner & + & + \\
2. Meyer & + & + \\
3. Dragendorf & + & + \\
Tanin & - & - \\
Saponin & + & + \\
Triterpenoid & - & - \\
Steroid & - & - \\
\hline
\end{tabular}

Berdasarkan pada hasil uji fitokimia menunjukkan bahwa pada ekstrak air dan etanol $70 \%$ hasilnya sama dalam keberadaan golongan senyawa kimianya terhadap jamur lingzhi. Berdasarkan pada Tabel 3 menunjukkan bahwa golongan senyawa kimia yang menunjukkan positif terdapat didalam jamur lingzhi adalah alkaloid dan saponin, sementara flavonoid, tanin, triterpenoid dan steroid memberikan respon yang negatif.

Hasil analisis diketahui bahwa sampel jamur lingzhi positif menggandung saponin yang ditandai dengan terbentuknya busa setelah pengocokan. Busa yang ditimbulkan 
saponin karena adanya kombinasi struktur senyawa penyusunnya yaitu rantai sapogenin non-polar dan rantai samping polar yang larut dalam air (Kristianingsih, 2005). Saponin adalah glikosida dalam tanaman dan terdiri atas gugus sapogenin, heksosa, pentosa, atau unsur asam uronat (Winarno, 2004). Menurut Robinson, (1995) adanya saponin dalam tanaman dapat bekerja sebagai antimikroba dan dapat digunakan sebagai bahan baku sintesis hormon steroid yang digunakan dalam bidang kesehatan. Golongan flavonoid, tanin, triterpenoid dan steroid tidak teridentifikasi pada ekstrak air dan etanol $70 \%$ pada jamur lingzhi.

\section{Rendemen Ekstrak Jamur Lingzhi Pada Berbagai Variasi Waktu Maserasi}

Ekstraksi jamur lingzhi dilakukan metode maserasi dengan membandingkan 2 pelarut yaitu sebanyak masing-masing $20 \mathrm{~g}$ simplisia jamur lingzhi dimaserasi dengan pelarut air dan pelarut etanol $70 \%$ sebanyak $1000 \mathrm{ml}$. Ekstraksi dilakukan dengan membandingkan lama perendaman yaitu maserasi 1 hari (24 jam), maserasi 2 hari (48 jam) dan maserasi 3 hari (72 jam). Perbandingan lama ektrasksi bertujuan untuk menentuan potensi aktivitas antioksidan terhadap lamanya maserasi.

Metode maserasi ini digunakan karena ekstraksi cara dingin sehingga tidak menggunakan suhu tinggi yang dapat merusak senyawa-senyawa yang memiliki aktivitas antioksidan yang terdapat dalam sampel jamur lingzhi. Keuntungan maserasi yaitu bahan yang sudah halus memungkinkan untuk direndam dalam pelarut sampai meresap dan melunakkan susunan sel sehingga zat-zat yang mudah larut akan terlarut (Febriani, 2015). Masingmasing dari hasil maserasi berupa maserat yang berwarna coklat tua dengan pelarut etanol $70 \%$ dan coklat muda menggunakan pelarut air. Pengentalan ekstrak dilakukan menggunakan rotary evaporator untuk menghilangkan pelarut yang masih berada di dalam ekstrak sehingga diharapkan ekstrak yang diperoleh merupakan komponen zat aktif yang terdapat pada jamur lingzhi (Budiarti, 2014). Maserat dipekatkan dengan rotary evaporator yang dilengkapi pompa vacum. Pompa vacum pada rotari evaporator berfungsi penguapan pelarut dapat dilakukan dibawah titik didih pelarut dan proses dapat berlangsung lebih cepat. Penguapan pelarut etanol $70 \%$ dapat dilakukan di bawah titik didihnya yaitu pada suhu $45^{\circ} \mathrm{C}$. Proses ini dilakukan pada suhu tersebut untuk menjaga senyawa aktif yang terkandung tidak rusak karena pemanasan. Prinsip kerja dari rotary evaporator yaitu proses pemisahan ekstrak dari cairan penyarinya dengan pemanasan yang dipercepat oleh labu.

Tabel 4. Rendemen Ekstrak Air dan Etanol $70 \%$ dengan Variasi Waktu Maserasi

\begin{tabular}{|c|c|c|c|}
\hline \multirow[b]{2}{*}{ Pelarut } & \multicolumn{2}{|c|}{ Rendemen (\%) } & Ekstrak \\
\hline & $\begin{array}{c}1 \text { hari } \\
(24 \text { jam })\end{array}$ & $\begin{array}{c}2 \text { hari } \\
(48 \text { jam })\end{array}$ & $\begin{array}{c}3 \text { hari } \\
(72 \text { jam })\end{array}$ \\
\hline Air & 4,60 & 4,78 & 4,98 \\
\hline Etanol $70 \%$ & 3,48 & 3,22 & 3,70 \\
\hline
\end{tabular}

Tingginya rendemen yang diperoleh dengan pelarut air yang mampu mengekstrak lebih banyak komponen bioaktif yang memiliki kepolaran yang lebih tinggi. Hasil penelitian menunjukkan kandungan senyawa pada jamur lingzhi yaitu Proscillaridin Proscillaridin merupakan salah satu senyawa dalam jamur lingzhi yang bersifat polar sehingga pada proses ekstraksi lebih banyak larut dalam air dari pada etanol $70 \%$. Hal tersebut menunjukkan pelarut memiliki peranan penting dalam proses ekstraksi. Berikut struktur dari Proscillaridin hasil dari penelitian.

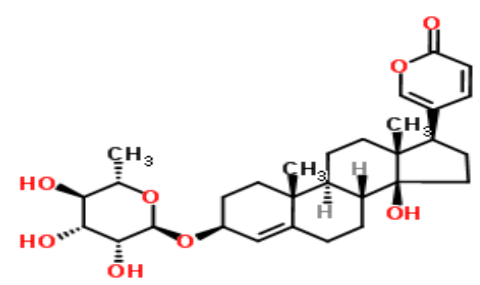

Gambar 2. Stuktur Proscillaridin 
Uji Aktivitas Antioksidan dengan 1,1diphenyl-2-picrylhydrazyl (DPPH)

Penelitian menggunakan Vitamin $\mathrm{C}$ sebagai standar karena masyarakat biasa mengkonsumsi vitamin sebagai penengkap radikal bebas dalam hal ini Gambaran tentang aktivitas antioksidan bila dibandingkan vitamin $\mathrm{C}$ yang sering digunakan. Penelitian melakukan pembuatan induk sampel dari ekstrak etanol $70 \%$ juga ekstrak air pada masing-masing lamanya perendaman, larutan sampel induk yang dibuat kemudian diencerkan dengan deret standar. Tujuan dari pembuatan variasi kadar ini bertujuan untuk memberi gambaran mengenai aktivitas antioksidan dari senyawa uji.

Aktivitas antioksidan ditentukan dari kemampuan senyawa yang terdapat dalam ekstrak yang menurunkan intensitas warna ungu radikal DPPH pada panjang gelombang maksimum. Penurunan intensitas ungu DPPH ini disebabkan oleh berkurangnya kromofor atau ikatan rangkap terkonjugasi pada senyawa DPPH, yang disebabkan oleh adanya ekstrak sebagai penangkap radikal akan mendonorkan atom $\mathrm{H}$ pada DPPH menjadi DPPH-H tereduksi yang menjadi warna kuning (Huang, 2005).

Warna kuning terbentuk setelah ditambah DPPH disebabkan oleh adanya senyawa yang dapat mendonorkan atom hidrogen di dalam ekstrak kloroform jamur lingzhi, sehingga dapat mengakibatkan molekul DPPH tereduksi yang diikuti dengan menghilangnya warna ungu dari larutan DPPH. Struktur DPPH dan DPPH tereduksi hasil reaksi dengan antioksidan dapat dilihat pada Gambar 3.

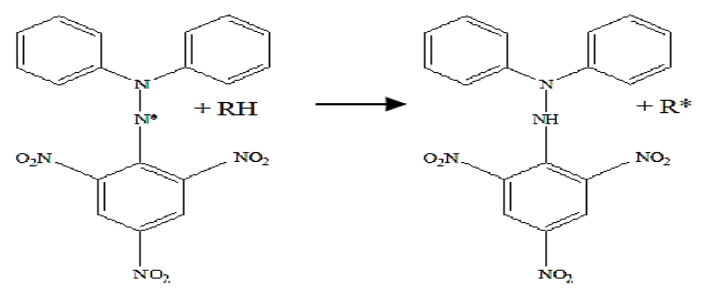

Gambar 3. Reduksi DPPH dari Senyawa Antioksidan (Prakash, 2001)
Berdasarkan hasil pengukuran vitamin $\mathrm{C}$ diperoleh nilai $\mathrm{IC}_{50}$ yaitu sebesar 11,0872 $\mu \mathrm{g} / \mathrm{ml}$. Nilai tersebut menunjukkan bahwa vitamin $\mathrm{C}$ memiliki aktivitas antioksidan yang sangat kuat karena memiliki nilai $\mathrm{IC}_{50}$ kurang dari $50 \mu \mathrm{g} / \mathrm{mL}$. Pengujian aktivitas antioksidan Vitamin $\mathrm{C}$ ini menghasilkan hubungan antara konsentrasi Vitamin C yang digunakan dengan persen inhibisinya, dapat dilihat pada Gambar 4.

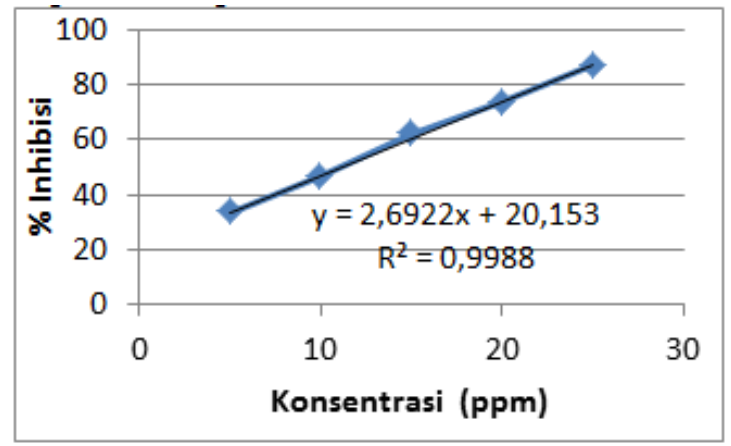

Gambar 4. Grafik Hubungan Konsentrasi Vitamin $\mathrm{C}$ dengan persen Inhibisi

\section{Identifikasi senyawa antioksidan dengan Liquid Chromatography Mass Spectrometry (LC-MS)}

Identifikasi ekstrak etanol $70 \%$ jamur lingzhi yang berpotensi sebagai antioksidan dalam penelitian menggunakan metode Liquid Chromatograph-Mass Spectrometry (LC-MS). Berikut kromatogram hasil identifikasi ekstrak etanol $70 \%$ jamur lingzhi. Hasil Kromatogram dari MS dapat dilihat pada Gambar 5.

Hasil yang diperoleh menunjukkan dalam ekstrak ekstrak etanol $70 \%$ menggandung fenolik dan alkaloid. Senyawa Bisphenol $M$ diduga merupakan senyawa golongan fenolik (Gambar 6). Menurut Gagola, (2004) bahwa senyawa fenolik memiliki aktivitas antioksidan. Sifat antioksidan senyawa ini berkaitan dengan keberadaan gugus fenolik yang dapat mendonorkan atom hidrogen pada suatu radikal bebas sehingga radikal tersebut menjadi tidak reaktif lagi sedangkan senyawa 1-\{[2-(3,4Dimethoxyphenyl)ethyl]amino -3 methyl 2-octylpyrido[1,2-a]benzimidazole-4carbonitrile diduga termasuk dalam 
golongan alkaloid. Menurut Hanani, (2015) .Hasil yang sesuai pada uji Fitokimia bahwa ekstrak etanol jamur lingzhi menggandung alkaloid. Alkaloid dapat berfungsi sebangai zat antioksidan

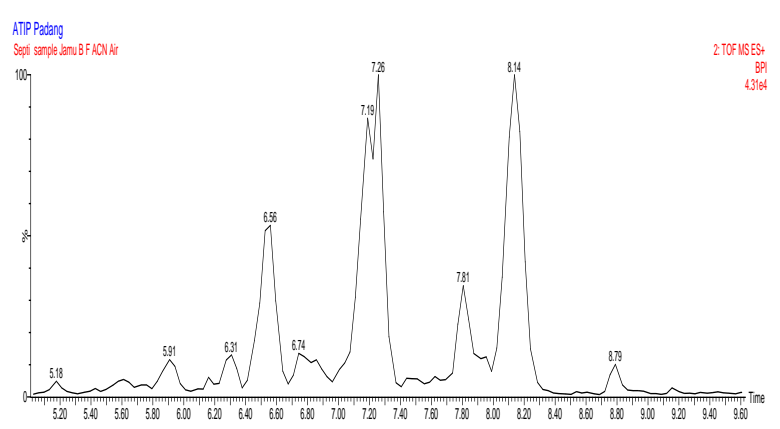

Gambar 5. Kromatogram Hasil Identifikasi Ekstrak etanol 70\% dengan LC- MS

Tabel 5. Identifikasi senyawa dalam ekstrak etanol $70 \%$ menggunakan database pada aplikasi Chemspider

\begin{tabular}{|c|c|c|c|c|c|}
\hline Larutan & $\begin{array}{l}\text { Lama } \\
\text { waktu } \\
\text { masersi } \\
\text { (Jam) }\end{array}$ & $\begin{array}{l}\text { Konsentrasi } \\
(\mathrm{ppm})\end{array}$ & $\begin{array}{l}\text { Serapan } \\
\text { sampel }\end{array}$ & $\begin{array}{l}\text { Hambatan } \\
(\%)\end{array}$ & $\mathrm{IC}_{50}$ \\
\hline \multirow{15}{*}{ Air } & \multirow{5}{*}{24} & 100 & 0,554 & 34,74 & \multirow{5}{*}{220,664} \\
\hline & & 200 & 0,416 & 51,001 & \\
\hline & & 300 & 0,387 & 54,416 & \\
\hline & & 400 & 0,214 & 74,793 & \\
\hline & & 500 & 0,150 & 82,332 & \\
\hline & \multirow{5}{*}{48} & 100 & 0,627 & 26,14 & \multirow{5}{*}{482,24} \\
\hline & & 200 & 0,594 & 30,03 & \\
\hline & & 300 & 0,532 & 37,33 & \\
\hline & & 400 & 0,483 & 43,10 & \\
\hline & & 500 & 0,400 & 52,88 & \\
\hline & \multirow{5}{*}{72} & 100 & 0,813 & 4,240 & \multirow{5}{*}{521,4} \\
\hline & & 200 & 0,707 & 16,48 & \\
\hline & & 300 & 0,646 & 23,91 & \\
\hline & & 400 & 0,583 & 31,33 & \\
\hline & & 500 & 0,408 & 51,94 & \\
\hline \multirow{15}{*}{$\begin{array}{l}\text { Etanol } \\
70 \%\end{array}$} & \multirow{5}{*}{24} & 100 & 0,424 & 50,058 & \multirow{5}{*}{94,83} \\
\hline & & 200 & 0,356 & 58,068 & \\
\hline & & 300 & 0,350 & 58,775 & \\
\hline & & 400 & 0,238 & 71,96 & \\
\hline & & 500 & 0,225 & 73,49 & \\
\hline & \multirow{5}{*}{48} & 100 & 0,527 & 37,92 & \multirow{5}{*}{287,57} \\
\hline & & 200 & 0,449 & 47,14 & \\
\hline & & 300 & 0,409 & 51,82 & \\
\hline & & 400 & 0,360 & 57,59 & \\
\hline & & 500 & 0,350 & 58,77 & \\
\hline & \multirow{5}{*}{72} & 100 & 0,723 & 14,84 & \multirow{6}{*}{509,670} \\
\hline & & 200 & 0,612 & 27,91 & \\
\hline & & 300 & 0,519 & 39,88 & \\
\hline & & 400 & 0,488 & 42,52 & \\
\hline & & 500 & 0,463 & 45,46 & \\
\hline Blangko & & 0 & 0,849 & & \\
\hline
\end{tabular}

\section{KESIMPULAN}

Berdasarkan hasil Penelitian dapat disimpulkan bahwa potensi aktivitas antioksidan yaitu hari maserasi 24 jam (1 hari) dengan nilai $\mathrm{IC}_{50} 94,83$ ppm dengan ekstrak etanol $70 \%$.Hasil identifikasi menggunakan LC-MS menunjukkan bahwa ekstrak jamur lingzhi dengan pelarut etanol $70 \%$ mengandung senyawa murni yaitu golongan fenolik : Bisphenol $\mathrm{M}$ dan golongan alkaloid 1-\{[2-(3,4Dimethoxyphenyl)ethyl]amino\}-3-methyl-2- 
octylpyrido[1,2-a]benzimidazole-4-

carbonitrile.

\section{DAFTAR PUSTAKA}

Budiarti, Mellia dan Rina Sri Kasiamdari. (2014). Pengaruh Modifikasi Media Budaya Jamur Tiram (pleurotus Ostreatus Jacq. Ex Fr. Kummer) Terhadap Morfologi, Pertumbuhan, dan Kandungan Protein. Skripsi. Universitas Gadjah Mada : Yogyakarta

Chow ST. WW Chaw and Chung. (2003) Antiokxidant activity and safety of 50 $\%$

ethanolic red bean extract (Phascolus raditus L Var Aurea). Journal of Food Science. Vol. 68(1); 21-25

Depkes RI. (2000). Parameter Standar Umum Ekstrak Tumbuhan Obat. Jakarta: Departemen Kesehatan RI. hal 5-11.

Febriani D, Dina M dan Endah R. (2015). Karakteristik Simplisia Dan Ekstrak Etanol $70 \%$ Daun Sirsak (Annona muricata Linn). Prosiding Penelitian SPeSIA Unisba : ISSN 2460-6472.

Gagola, C et al. (2004). Aktivitas Antioksidan dari Ekstrak Fenolik Cortex Umbi kayu (Manihot esculenta) Daging putih dan daging kuning yang diambil dari kota melonguane kabupaten kepulauan talaud. Jurnal ilmiah farmasi pharmacon. Vol 3 (2). ISSN 23022493.

Hanani et al. (2015). Identifikasi Senyawa Antioksidan dalam Spon Callyspongia SP dari Kepulauan Seribu. Majalah
Ilmu Kefarmasian II. (3), Halaman 130.

Huang, D and Prior R.L. 2005. The Chemistry Behind Antioxidan Capacity Assays. Journal of Agricultural And Food Chemistry. 53:1841-1856.

Jaelani. (2008). Jamur Berkhasiat Obat. Jakarta: Pustaka Obor Populer. Hal: 61-70.

Kristianingsih. (2005). Isolasi dan Identifikasi Senyawa Terpenoid dari Akar Tanaman Kedondong. Skripsi. Institut Pertanian Bogor.

Menkes. (1994). Persyaratan Obat tradisional. Jakarta : Mentri kesehatan.

Middleton E, C Kandaswami \& TC Theoharides. (2000). The effects of plant flavonoids on mammalian cells: implications for inflammation, heart disease, and cancer. Pharmacological Reviews. 52. 673-751.

Prakash, A., Rigelhof, F., Miller, E. (2001). Antioxidant Activity. Journal Medalliaon Laboratories Analitycal Progress: Vol 10(2).

Robinson, T., (1995). Kandungan organik Tumbuhan Tinggi, Edisi VI, Hal. 191216, Diterjemahkan oleh Kosasih Padnawinata, ITB, Bandung.

Sasikumar, J. M., U. Jinu and R. Shamna. (2009). Antioxidant Activity and HPTLC Analysis of Pandanus odoratissimus L. Root. European Journal of Biological Sciences Vol. 1(2): $17-22$.

Winarno F.G. (2004). Kimia Pangan dan Gizi. Jakarta: Gramedia Pustaka Utama 